\title{
Morphology and fine structure of two marine tubificids (Oligochaeta), closely related to the gutless Phallodrilus spp.
}

\author{
O. Giere \\ Zoologisches Institut und Zoologisches Museum, Universität Hamburg; \\ Martin-Luther-King-Platz 3, D-2000 Hamburg 13, Federal Republic of Germany
}

\begin{abstract}
The morphology and ultrastructure of the two interstitial marine tubificids Phallodrilus prostatus and Aktedrilus monospermathecus (Oligochaeta), closely related to the gutless Phallodrilus spp., is described. Since pertinent histological descriptions of 'regular' marine tubificids were found to be non-existent, this study provides a structural basis allowing comparisons both with limnetic species and the recently described marine anenteric forms. Compared to the few freshwater tubificids investigated histologically, major differences are the substitution of the dorsal blood vessel by a large sinus, the close contact between nephridial tissue and the subintestinal vessel, a characteristic 'wavy' arrangement of cuticular collagen fibres, and the formation of branched epicuticular projections. The structural divergences from the gutless relatives refer mainly to the body wall, the vascular system and its endothelial structure. The various peculiarities outlined here indicate that generalizations of the situation as found in the few histological studies are as yet problematical.
\end{abstract}

\section{INTRODUCTION}

In a special research project, the gutless oligochaete Phallodrilus leukodermatus from Bermuda is the subject of thorough examination (Giere, 1979, 1981; Giere et al., 1982, 1983). This species has, in contrast to the anenteric Pogonophora, close relatives which possess a regular digestive and excretory system. However, direct comparisons have been impossible so far due to the lack of information on the structure of these 'normal' forms. Both in classical monographs on oligochaete morphology (Stephenson, 1930) and recent compilations of their ultrastructure (Jamieson, 1981), marine tubificids have been disregarded. Hence, the first aim of this study was to establish a basis for comparison between 'regular' and extremely modified forms by examining two common species, taxonomically and ecologically close to the gutless worms, the interstitial congener Phallodrilus prostatus and a representative from a related genus, Aktedrilus monospermathecus.

However, since morphological and histological knowledge was found to be based, also in freshwater tubificids, on only very few species (mainly Tubifex tubifex and Limnodrilus spp., see 'Discussion'), it was felt that this work should not restrict itself to selected ultrastructural details, but should cover the gross-morphological organization 
by use of light- and low power-electron microscope, and scrutinize some more relevant organs (vascular system, nerve cord, epidermis/cuticle complex) at the subcellular level.

\section{MATERIAL AND METHODS}

Phallodrilus prostatus (Knöllner, 1935) was collected in October 1982 at the beach in Strande (Kiel-Fjord, Baltic Sea; salinity ca $15 \%$ ). The worms were decanted from medium to coarse sand slightly above the water line in ca $20 \mathrm{~cm}$ depth just above groundwater level. Aktedrilus monospermathecus (Knöllner, 1935) was collected in October 1982 from the sandy upper shore at Keitum (Isle of Sylt, North Sea) $2 \mathrm{~m}$ from highwater line at a depth of ca 30-40 cm (interstitial salinity $22 \%$, medium sand).

One day after sampling, adult worms without developed genital organs were fixed and prepared for microscopy: fixation for $2 \mathrm{~h}$ in $5 \%$ glutaraldehyde buffered in $0.1 \mathrm{~m}$ Na-Cacodylate with $7 \%$ sucrose, $\mathrm{CaCl}_{2}$ and $\mathrm{MgCl}_{2}$ added (according to Pearse, 1972); $2 \% \mathrm{OsO}_{4}$ for $1 \mathrm{~h}$, acetone, Spurr's resin (all procedures at $4{ }^{\circ} \mathrm{C}$ ). Ultrathin sections (Reichert OM U2) were stained with uranylacetate $(5 \mathrm{~min})$ and leadcitrate $(1 \mathrm{~min})$ for electron microscopy (Zeiss EM 9S-2); $1 \mu \mathrm{m}$-sections were stained with toluidine-blue/ pyronine for light microscopy (Zeiss-Axiomat). This study is confined to cross sections through the postclitellar, central parts of the worm's body. It omits complicating structures such as setae with their special musculature and the genital organs.

\section{RESULTS}

\section{Phallodrilus prostatus}

Light-microscopic survey

The dominating structure is the voluminous intestine with a well developed lumen with long cilia extending into it from the inner surface of the wall cells (Fig. 1a). The enteric wall is surrounded by a large sinus complex of irregular width. Even the large 'dorsal blood vessel' lacks an endothelial lining, i.e. it has to be regarded as a wide sinus (Figs 1a, 1d). The ventral blood vessel is relatively small and, if not filled with blood, sometimes hardly discernible under the light microscope. Through peristaltic movements of the body it is often found dislocated from its median subintestinal location above the ventral nerve cord into a position lateral to the neural tissue. A subneural longitudinal vessel is absent. A paired arrangement of nerve trunks in the ventral cord could not be detected histologically.

The chloragogenic tissue forms a thick layer on the dorsal and latero-dorsal parts of the gut enclosing the large blood plexus, while it covers the gut in a thin layer along the lateral and ventral parts of the intestinal tube. The coelomic cavity is wide in the dorsolateral parts of the body; it narrows latero-ventrally where its lumen is filled with large nephridia, the nerve cord and often the oblique setal musculature. The considerable size of each excretory organ is indicated by the fact that nephridial tissue, mostly divided in several lobed portions is to be encountered in almost every section (Fig. 1b). The outer mesodermal wall of the coelome, a thin, but clearly discernible peritoneal lining, 
belongs functionally to the relatively tenuous parietal wall. Here, well developed longitudinal muscles are enclosed by a frail ring of circular musculature. The epidermis with conspicuous nuclei secretes a clearly visible cuticle.

\section{Transmission-electron-microscopic observations}

The active metabolic function of the intestinal cells becomes evident in the light of their vast organelle content (Fig. 1c): the compact cytoplasm, highly enriched with glycogen rosettes, is crammed with mitochondria of rather irregular cristae structure. The dense endoplasmatic reticulum is lined with ribosomes. Golgi bodies and large nuclei are regularly visible while there are only few vesicular inclusions. The cells extend into the inner intestinal lumen through a dense layer of cilia $(9+2$ pattern); the outer cell surface is in close contact with the circumintestinal blood plexus. The inconspicuous intestinal musculature consists of small portions of longitudinal fibres and a narrow inner ring of circular fibres, and separates the intestinal cells and blood sinus from the mesodermal chloragocytes.

Without going into the details of development and nomenclature of chloragogenic tissue (see Jamieson, 1981), description will be confined here to one cell category, the large and irregularly shaped chloragocytes, centres of oligochaete metabolism (Fig. 1d). They carry rich amounts of glycogen rosettes. Their cytoplasm appears flimsy due to the many membrane-bound lipid (?) droplets of varying electron density filled with an amorphous mass. Further characteristic organelles are the numerous electron dense 'chloragosomes' and, especially in ergastoplasmatic stages (Jamieson, 1981), the stacked system of plasmatic reticula packed with ribosomes, the huge nucleus and the common mitochondria with their dense matrix and small, irregular cristae. Also the thin peritoneal cells at the outer edge of the coelomic cavity contain numerous mitochondria.

While a dorsal contractile blood vessel is substituted by a mere blood sinus (Figs $1 \mathrm{a}$, d), the wall of the subintestinal vessel is supplied with musculature consisting of about six bundles of inner longitudinal myofibrils and very fine outer circular strands (Fig. 2a). In the fine-granular blood plasma no hemocytes or blood eleocytes (Jamieson, 1981) have been encountered.

The ventral blood vessel is always closely associated with the nephridial tissue of the vascular walls (Fig. 2b). In this distal, ventro-lateral portion of the nephridium, the tissue is characterized by extensive folding of cellular lamellae (Fig. 2b). Cross sections through these slim folds reveal circular to oval structures. Since only small parts of the much twisted nephridial canal have been cut, it appears slitlike or tubelike. Especially in the proximal portion of the nephridium, the dense plasma shows mitochondria, many minute tubular structures, an endoplasmatic reticulum with ribosomes and some elongate nuclei.

The perineural sheath around the ventral nerve cord (Fig. 2c) is only dorsally well developed. It consists mainly of longitudinal musculature, but lacks blood vessels. The tubules traversing the muscle fibres are directed at right angles towards the nerve cord. Neuroglial cells with their conspicuous nuclei can be encountered at the ventral edge of the nerve cord, but never form a marked glial 'layer'. The neuropile with its characteristic mesh-like tissue of neuronal processes contains only few mitochondria and is of a very uniform structure through the absence of giant fibres. In the parietal musculature (Fig. 2d), the predominant layer is the inner 'ribbon' of longitudinal myofibres (one fibre 
deep) hanging on a thin basement membrane and enclosed in a fine sarcolemma. The peripheral sarcoplasma, showing many glycogen rosettes, contains the nucleus and is densely packed with mitochondria. Small triangular fibres are irregularly spaced
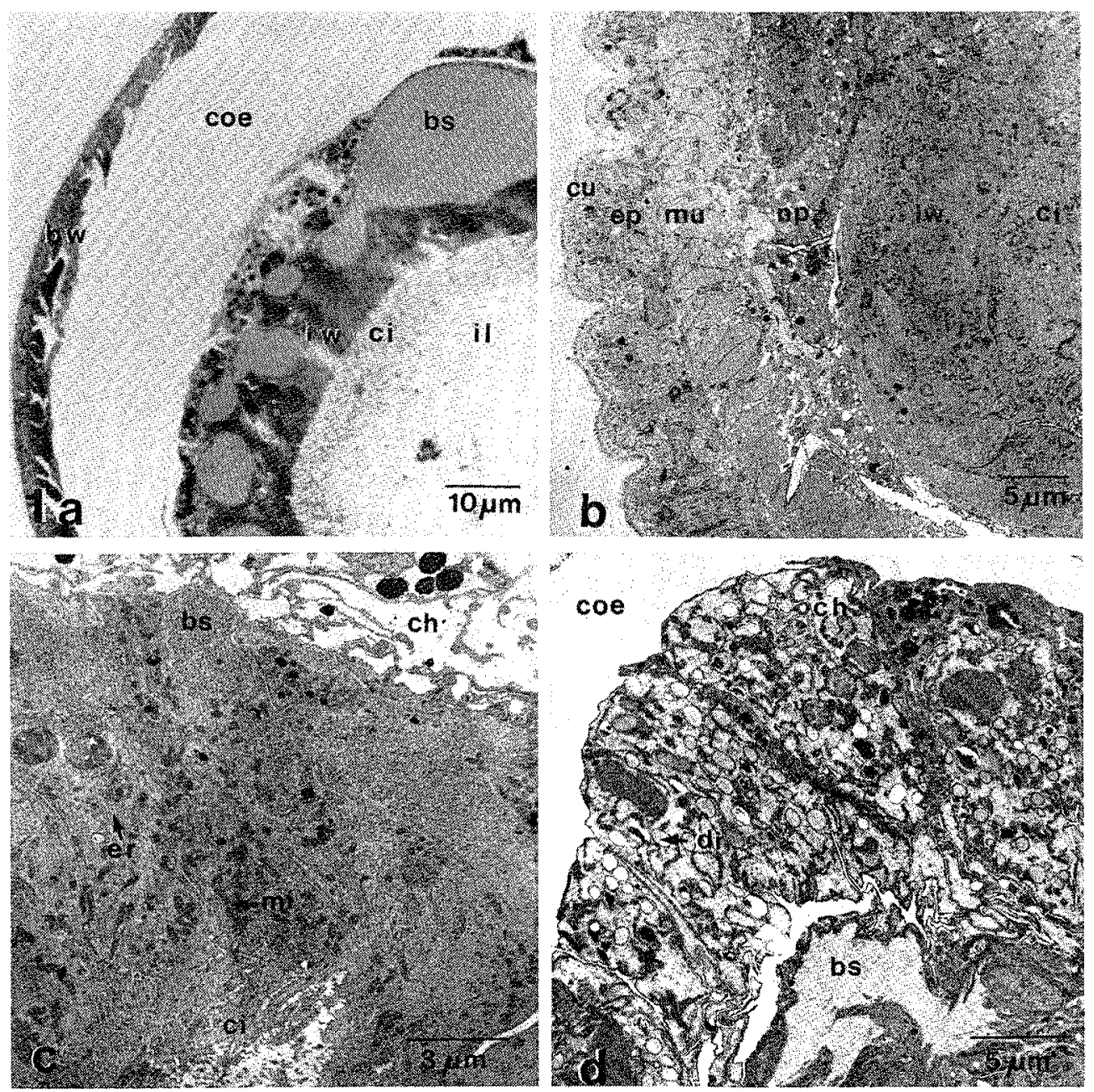

Figs 1-2: Phallodrilus prostatus. Fig. 1a: Light microscopic foto; Figs 1b-2f: TEM fotos; (1a) Dorso -lateral half-section. (1b) Section through lateral parts of body. (1c) Intestinal cell. (1d) Chloragocytes and dorsal blood sinus. (2a) Ventral blood vessel. (2b) Folded lamellae in distal nephridial tissue. (2c) Ventral nerve cord with cover of musculature. (2d) Body wall. (2e) Epidermis cell. (2f) Cuticle traversed by microvilli. Abbreviations: $b s=b l o o d$ sinus, $b v=b l o o d$ vessel, $b w=b o d y$ wall, $\mathrm{ci}=$ cilia of gut, $\mathrm{ch}=$ chloragocytes, $\mathrm{cmu}=$ circular parietal muscles, coe $=$ coelomic cavity, $\mathrm{cof}=$ collagen fibres, $\mathrm{cs}=$ chloragosomes, $\mathrm{cu}=$ cuticle, $\mathrm{dr}=$ droplets, ep = epidermis, epidermal cell, epr = epicuticular projections, er = endoplasmatic reticulum, go = Golgi vesicles, il = intestinal lumen, $i \mathrm{w}=$ intestinal wall, $\mathrm{lmu}=$ longitudinal parietal muscles, $\mathrm{mi}=$ mitochondrium, $\mathrm{ms}=$ myosare with mitochondria, $\mathrm{mu}=$ musculature, $\mathrm{mv}=$ microvilli, ne = nerve cord, neg$=$ neuroglia (nucleus), nep = neuropile, $\mathrm{nmu}=$ musculature around nerve cord, $\mathrm{np}=$ nephridium, nephridial tissue, $\mathrm{nu}=$ nucleus, $\mathrm{vs}=$ vesicle 

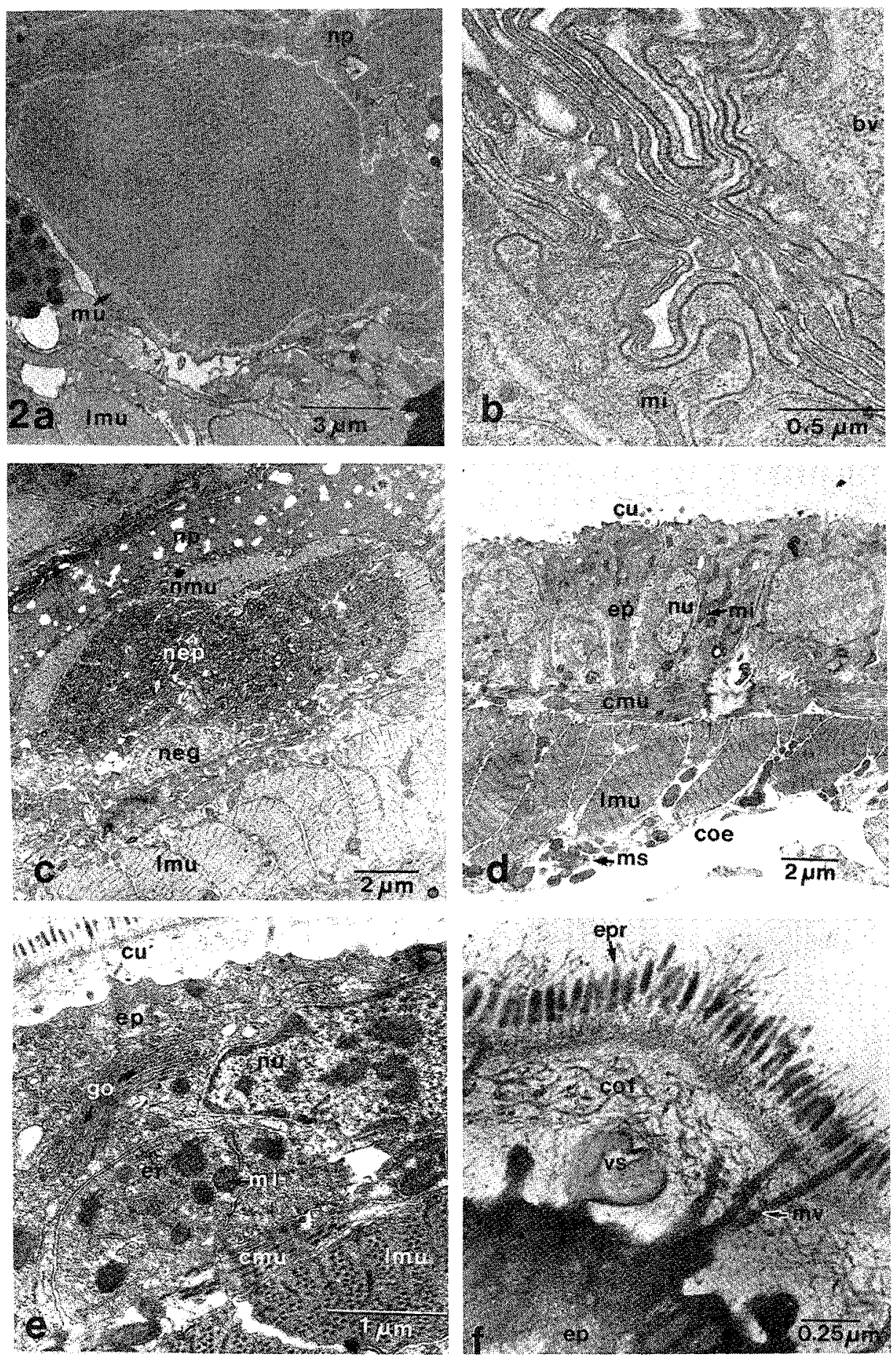

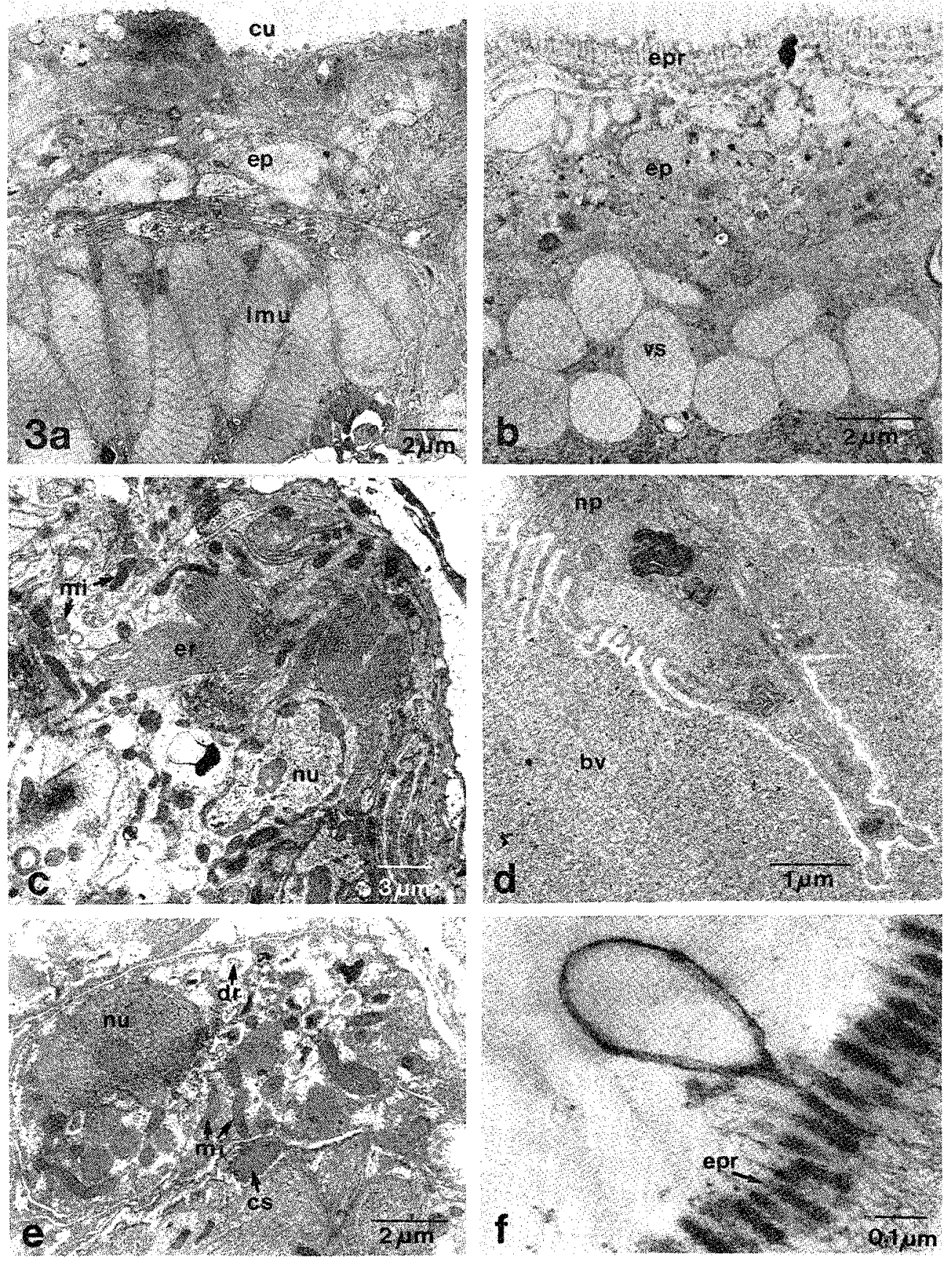

Figs 3a-f: Aktedrilus monospermathecus. TEM fotos, for abbreviations see legends to Figs 1-2. (3a) Body wall. (3b) Mucous (?) droplets in epidermal cell. (3c) Intestinal cell with dense endoplasmatic reticulum. (3d) Nephridial wall folded in blood vessel lumen. (3e) Chloragocyte. (3f) Excretion (?) of membrane-bound 'bubble" 
between the larger normal longitudinal myofibres. Both types are traversed by sarcoplasmatic reticulum tubules extending from the peripheral plasmalemma at oblique to right angles and subdividing the thick myofilaments in regular compartments of three to four parallel filamental rows. Thin filaments surrounding the thick ones (Jamieson, 1981) could not be observed. In the outer single band of circular muscle fibres, separated from the longitudinal ones by the basement membrane, sarcotubules are absent. Here, the sarcoplasma with its mitochondria extends externally towards the epidermis, from which it is set off only by a thin membrane.

The typical epidermis cell ("supporting cell", Jamieson, 1981) is more or less cuboidal, higher than wide (Fig. 2d), with a large nucleus and cytoplasma rich in glycogen rosettes. There is a dense endoplasmatic reticulum and numerous Golgi (Fig. 2e). Mitochondria are frequent, while excretory activity, judging from the occurrence of droplets and mucus cells, seems moderate in this species (see below).

The external surface of the epidermal cells is highly digitated forming irregular columnar supports which branch or simply taper into long microvilli. The cuticle, traversed by these microvilli, consists of a thick matrix $(550 \mathrm{~nm})$ with an irregular pattern of thin collagen fibres (Fig. 2f) and an epicuticle $(140 \mathrm{~nm})$ with a somewhat condensed fibrillar structure, not set off sharply from the basal layer. Very numerous epicuticular projections (175 nm long, $36 \mathrm{~nm}$ wide, 65-70 nm centre-to-centre distance) extend from the surface. They stand on fine pedestals and carry at their tips long, brush-like branches. Some sections depicted mucus floccules coming off the tips of the epicuticular projections.

\section{Aktedrilus monospermathecus}

\section{Light-microscopic survey}

Ecologically similar to $P$. prostatus, this species also inhabits the interstitial region of the high-water zone of sandy beaches. The worm is taxonomically very closely related to the other species studied here and for a time it was included in the genus Phallodrilus (Brinkhurst \& Jamieson, 1971).

Sections through $A$. monospermathecus show a parietal musculature with somewhat thicker longitudinal fibres. Substantial differences at the light-microscopic level could not be detected.

\section{Transmission-electron-microscopic observations}

Here, the prominent longitudinal muscle fibres in relation to the worm's diameter are conspicuously depicted (Fig. 3a), but in structural details they do not seem to differ from $P$. prostatus. However, the integument is distinguished by an augmented excretory activity: vesicles occur regularly; membrane-bound spheres arise from the epicuticular projections (Fig. 3f) and cells filled with droplets are mixed with the supporting epidermal cells (Fig. 3b). These exhibit at their surface many digitiform branches which merge into long microvilli. The epicuticular projections are of the same shape and size as in $P$. prostatus. The fibre system in the cuticular matrix is also similarly wavy and irregular.

Other organs, with identical or slightly diverging structure:

- In the cells of the intestinal wall, the endoplasmatic reticulum lined with ribosomes (Fig. 3c) is the dominating organelle beside the large nucleus; but this extreme development may be due to limited activity phases only. 
- The ventral nerve cord seems less clearly covered by discontinuous longitudinal muscles on the dorsal side. Ventrally, a massive layer of glia cells with marked nuclei underlies the central neuropile which, again, lacks giant fibres.

- The ventral blood vessel, always in close contact with the adjacent nephridial tissue, is often found laterally dislocated. A corresponding dorsal vessel does not exist. As in $P$. prostatus it is substituted by a large sinus which merges into the intestinal plexus.

- Location and structure of chloragogenic cells is similar to $P$. prostatus: especially around the dorsal sinus, they form an irregular layer of large, fluffy cells, varying in shape, with large nucleus, many organelles, glycogen rosettes and droplets, indicating their active metabolism (Fig. 3e).

\section{DISCUSSION}

In the first part, the body structure of Phallodrilus prostatus and Aktedrilus monospermathecus, as evident from cross sections, will be compared with that of other oligochaetes, in particular tubificids; the second part will discuss the results in relation to the gutless Phallodrilus spp.

In view of the scarce and scattered specific anatomical-histological literature on tubificids, the general reviews of Stephenson (1930), Brinkhurst \& Jamieson (1971), and Jamieson (1981) in addition to some original papers were used here as a source of information. However, on scrutinizing literature for details of the different organ systems, the meager extent of information on tubificids becomes apparent, particularly with reference to ultrastructure as summarized by Jamieson (1981). Here, the alimentary canal and the excretory system of Tubificidae are only vaguely mentioned, the description of nerve cord, musculature and integument is mostly restricted to Tubifex tubifex and, to some extent, to Limnodrilus spp. Hence, so far, many literature 'results' on Tubificidae are, in fact, extrapolations from facts obtained from other oligochaete groups. The ultrastructure of the increasing number of species in the marine subfamily Phallodrilinae is completely unknown except for that of two gutless forms.

While the chloragocytes and musculature of the two 'regular' marine tubificids studied here do not apparently differ much in ultrastructure from some other tubificids with gut or even from other families (chloragocytes of $T$. tubifex: Lindner, 1965; Fischer \& Horváth, 1978, 1979; other families: Jamieson, 1981; musculature of $T$. tubifex and Limnodrilus udekemianus: Lanzavecchia, 1971), major organ systems are divergent in the two examined species compared with literature reports.

\section{Structure of the nerve cord}

While for T. tubifex (Dixon, 1915), L. hoffmeisteri (Satija \& Garg, 1976) and, finally, for microdriles as a whole (Cook, in Brinkhurst \& Jamieson, 1971) giant dorsal fibres were described and the double structure of the clearly ensheathed nerve trunks reported to be of general occurrence, there is no sign of these structures in the worms studied here. A "fibrous capsule" covering the nerve cord is missing.

\section{Dorsal blood vessel}

This vessel, designed by Dixon (1915) with an own vascular wall for $T$. tubifex and later repeatedly studied in Tubificidae (see literature in Brinkhurst \& Jamieson, 1971), is 
lacking in the two phallodriline marine species in question. Here, the corresponding structure clearly has open connections to the intestinal sinus-complex and, in contrast to the ventral vessel, lacks endothelial lining (Fig 1a, 1d). Since Dixon (1915) does not differentiate between 'vessel' and 'sinus', the "supra-intestinal vessel", described by her as giving rise to the "intestinal vessels" may in fact represent a large dorsal blood sinus.

The intimate connection between the ventral blood vessel and the excretory system in $P$. prostatus and A. monospermathecus is documented by folds in the vascular wall, with nephridial tissue projecting into the vessel lumen or even by 'branches' protuberating into it (Fig. 1f). A similarly close alliance with the branches was described by Nasse (1882, in Dixon, 1915) for Tubificidae, but later rejected by Vejdovsky (1884) and Dixon (1915). However, close physiological connection between blood and nephridia is stressed even in recent contributions (see Jamieson, 1981).

Graszynski (1963) found in Lumbricus terrestris a plasmatic structure in the nephridial wall showing characteristic lamellae and circular sections with mitochondria. His figures resemble very closely the micrographs given in this study (Fig. 2b), so that they, with some probability, represent sections through the plasmatic wall of the distal nephridial canal ("Stäbchenkanal" in Graszynski, 1963; perhaps "porción C' in Peña, 1978).

\section{Cuticle}

The conspicuous pattern of regularly crossing collagen fibres, typical for some lumbricids and enchytraeids (Richards, 1977), is not present in the marine tubificids inspected here. Their irregular wavy fibres, running mainly in a circular direction, bear more resemblance with the cuticle in the naidid Dero obtusata (Krall, 1968). In this pattern they contrast to the gutless Phallodrilus species (Giere, 1981; Richards, Fleming \& Jamieson, 1982) which show an orthogonal collagen grid. This difference within families and even within one genus of interstitially living worms renders generalization or relation of these cuticular structures to life habits problematical (Richards, 1977; Westheide \& Rieger, 1978).

The shape and size, too, of the epicuticular projections seem to vary considerably (Jamieson, 1981). Both Tubifex tubifex (Fischer \& Horváth, 1977) and the gutless relatives have shorter and simple epicuticular projections which lack any brush-like tips (Giere, 1981; Richards et al., 1982). This leaves room for speculation on the function of these structures, whether as means for the transepidermal uptake of nutrients or, as suggested by Richards et al., (1982), for mere protection.

This leads to a further comparison with the anatomy of the two gutless Phallodrilus species, with the restriction that in $P$. albidus (Richards et al,, 1982), only the distal epidermis and cuticle have been described. In P. leukodermatus (Giere, 1981), the most striking difference, the complete absence of gut and nephridia, has apparently marked consequences for the structure of the vascular system and chloragocytes: while in the 'normal' worms the vessels are via the chloragogenic tissue in loose connection with the intestine and nerve cord, in the anenteric form the two large longitudinal vessels, connected by a muscular strand, traverse more or less freely the 'empty' coelomic cavity. Hence, any homology for a ventral or dorsal vessel is here problematical. The endothelial cells, too, have attained a different appearance in the gutless coelome: they seem 'blown up' and, in some sections, fill the whole cavity almost resembling a fluffy 
mesenchyma (Fig. 1 in Giere, 1981). Their rich content of endoplasmatic reticulum, lined by ribosomes, mitochondria, electron-dense grana, however, functionally resembles normal chloragocytes (see above). Transformation of the integument through the incorporation of bacteria (Giere et al., 1983) has modified the epidermis/cuticle complex in both gutless species compared to the regular epidermis as described above. Lacking 'cavities' at the epidermis - cuticle interface for storage of bacteria and multi-vesicular bodies, the dermal layer, here, is less thick than the corresponding 'mantle' of $P$. leukodermatus which attains almost half the diameter of the cross section (Fig. 1 in Giere, 1981). However, excretion of membrane-bound 'bubbles', apparently mediated by the epicuticular projections (Fig. 6 in Giere et al., 1983), occurs both in P. leukodermatus and the species described here (Fig. 3f).

\section{Musculature}

The longitudinal muscle fibres of both gutless species differ in the enlargement of the sarcoplasmatic, noncontractile portion of the cell which 'hangs' into the coelomic cavity, and which in some sections (see Fig. 1 in Giere, 1981) is as large as or larger than the fibrous part (see also Jamieson, 1981). Small triangular muscle cells are embedded in the normal longitudinal musculature. They are apparently a common feature in tubificids as shown for Tubifex tubifex, P. prostatus and A. monospermathecus, but occur in $P$. leukodermatus in increased number and in particularly regular arrangement. In this species the ultrastructure of the longitudinal muscles differs from that of the species examined above, each (thick) myofibril being encircled by thin fibrils.

\section{Nerve cord}

In contrast to the two 'normal' phallodriline worms inspected in this study, the nerve cord of $P$. leukodermatus harbours two or three larger dorsal fibres. However, since their diameter is much less distinct than that of the prominent 'giant fibres' in Lumbricus terrestris (Jamieson, 1981) or Tubifex tubifex (Dixon, 1915), it cannot be stated at this stage that they really are their equivalent. Only in some sections through $P$. leukodermatus is a slight bipartition in two neural trunks visible.

\section{CONCLUSIONS}

The marine Phallodrilinae, studied here for the first time, exhibit major morphological and histological differences from the known limnic Tubificinae. This refers mainly to the histology of the nerve cord, arrangement of the vascular system and ultrastructure of the cuticle. Compared to the 'regular' Phallodrilinae, degeneration of the gut and nephridia in the recently discovered anenteric relatives has deeply changed the body organization: not only has the dermal wall specialized by the uptake of symbiotic bacteria, but also the structure of the longitudinal musculature and the endothelial tissue which accompanies the large blood vessels in the 'empty' coelomic cavity have undergone modifications.

Further structural investigations on other gutless oligochaete species (Giere, in preparation) will ascertain whether these 'derivations' are of a more general nature or 
differ in each anenteric species. However, it has already become clear that a reliable histological and cytological assessment of the aberrant gutless situation is only feasible in the light of the 'normal' organization as shown in related worms from the marine biota. Therefore, generalizations from the few scattered studies on freshwater tubificids or even other families are misleading and less than helpful.

Acknowledgement. My thanks to Dr. O. Pfannkuche for his cooperation.

\section{LITERATURE CITED}

Brinkhurst, R. O. \& Jamieson, B. G. M., 1971. Aquatic Oligochaeta of the world. Oliver \& Boyd, Edinburgh, $860 \mathrm{pp}$.

Dixon, G. C., 1915. Tubifex. - L. M. B. C. Mem. typ. Br. mar. Pl. Anim. 22, 1-100.

Fischer, E. \& Horváth, I., 1977. Cytochemical studies on the cuticle and epidermis of Tubifex tubifex Müll. with special regard to the localization of polysaccharides, heavy metals and the DABreactivity. - Histochemistry 54, 259-271.

Fischer, E. \& Horvatth, I., 1978. Cytological and cytochemical studies on the chloragocytes of Tubifex tubifex Müll. with special regard to their role in heme-metabolism. - Zool. Anz. 201, 31-43.

Fischer, E. \& Horváth, I., 1979. The effect of environmental oxygen concentration on the chloragocytes of Tubifex tubifex Müll. - Zool. Anz. 203, 283-288.

Giere, O., 1979. Studies on marine Oligochaeta from Bermuda, with emphasis on new Phallodrilusspecies (Tubificidae). - Cah. Biol. mar. 20, 301-314.

Giere, O., 1981. The gutless marine oligochaete Phallodrilus leukodermatus. Structural studies on an aberrant tubificid associated with bacteria. - Mar. Ecol. Prog. Ser. 5, 353-357.

Giere, O., Liebezeit, G. \& Dawson, R., 1982. Habitat conditions and distribution pattern of the gutless oligochaete Phallodrilus leukodermatus. - Mar. Ecol. Prog. Ser. 8, 219-299.

Giere, O., Felbeck, H., Dawson, R. \& Liebezeit, G., 1983. The gutless oligochaete Phallodrilus leukodermatus Giere (Tubificidae), a structural, ecological and physiological novelty. - Hydrobiologia (in press).

Graszynski, K., 1963. Die Feinstruktur des Nephridialkanals von Lumbricus terrestris L. Eine elektronenmikroskopische Untersuchung. - Zool. Beitr. 8, 189-296.

Jamieson, B. G. M., 1981. The ultrastructure of the Oligochaeta. Academic Press, London, 462 pp.

Krall, J. F., 1968. The cuticle and epidermal cells of Dero obtusata (family Naididae). - J. Ultrastruct. Res. 25, 84-93.

Lanzavecchia, G., 1971. Studi sulla muscolatura elicoidale e paramiosinica. Nota IV. La muscolatura longitudinale e circolare della parete corporea degli Annellidi Tubificidi. - Atti Accad. naz. Lincei Rc. 50, 6-12.

Lindner, E., 1965. Der periintestinale Blutsinus der Anneliden. - Verh. anat. Ges., Jena 115, 377-379.

Nasse, D., 1882. Beiträge zur Anatomie der Tubificiden. Diss., Univ. Bonn, 32 pp.

Pearse, A. G. E., 1972. Histochemistry. Livingstone, Edinburgh, 2, 761-1518.

Peña, E. de la, 1978. Estudio ultra structural en Octolasium cyaneum (Sav.) (Oligochaeta) des las porciones de reabsorción y regulación osmótica del nefridio. - Boln R. Soc. esp. Hist. nat. (Biol.) $76,39-47$.

Richards, K. S., 1977. Structure and function in the oligochaete epidermis (Annelida). - Symp. zool. Soc. Lond. 39, 171-193.

Richards, K. S., Fleming, T. P. \& Jamieson, B. G. M., 1982. An ultrastructural study of the distal epidermis and the occurrence of subcuticular bacteria in the gutless tubificid Phallodrilus albidus (Oligochaeta: Annelida). - Aust. J. Zool. 30, 327-336.

Satija, R. C. \& Garg, D., 1976. Histology of the central nervous system of some annelids. III. Central nervous system of Limnodrilus hoffmeisteri. - Res. Bull. Panjab Univ. Sci. 27, 11-19.

Stephenson, J., 1930. The Oligochaeta. Oxford Univ. Press, Oxford, $978 \mathrm{pp}$.

Vejdovsky, F., 1884. System und Morphologie der Oligochaeten. Ǩivnáč, Prag, 166 pp.

Westheide, W. \& Rieger, R. M., 1978. Cuticle ultrastructure of hesionid polychaetes (Annelida). Zoomorphologie 91, 1-18. 